〔ミニレビュー〕

\author{
ゲノム選抜法 \\ 富樫研治 \\ （独）農研機構北海道農業研究センター、 $=062-8555$ 札棍市農平区羊ヶ 丘 1 番地
}

\title{
Genomic selection
}

\author{
Kenji TOGASHI
}

National Agricultural Research Center for Hokkaido Region

\section{1. アメリカ農務省から発表されたゲノム育種価}

2009 年 1 月、アメリカ農務省は、ゲノム育種価を公 表した。ゲノム育種価は、従来の育種価が多くの未知 の遺伝子が持つ小さな効果について個々の遺伝子の効 果の大きさの推定を行わずに、その総和 1 つに単純化 して遺伝的能力を表してきたのに対し、ゲノム全体に 頻繁に多数分布するマーカーを利用して、個々のマー カーの効果をそれぞれ推定してその和を計算したも のとして表される。このような目的に用いるマーカー として一塩基多型（SNP）が考えられており、SNPは DNA を構成する塩基の 1 つが A から B に変わること によって起こる多型で、その変異はゲノム全体に頻繁 に多数分布している。SNPは、アメリカの民間会社 により簡単に分析する器材 (Bovine SNP50 Genotyping BeadChip）が開発されており、現在、牛では54,000 カ 所ほどの多型を同時に検出することができる。した がって、QTL（量的形質遺伝子座）が SNP マーカーと 強い関連性（連鎖不平衡）を持てば、QTL が不明でも それと関連している SNP マーカーを基にQTLの効果 を推定できる。QTLと SNP マーカー間の連鎖不平衡 については、次のように考えられる。例えば、過去に QTL で突然変異が起こり乳量を増やしたとする。この ような突然変異（塩基の置換や欠失等）は偶然に起こ る。この QTL の近くにマーカーがある。例えば、マー カーのタイプを $\mathrm{M}$ (頻度 $: \mathrm{p})$ と $\mathrm{m}$ （頻度：1-p）とし、 QTL のタイプを乳量が多くなったものを T (頻度 : q $) 、$ 変異の無かったものを $\mathrm{t}$ (頻度 : 1-q） とすると、変異 が起こった世代以降のマーカーと QTL の組み合わせは M-T, M-t, m-T, m-t となり、それらの頻度は、pq, p (1-q)， (1-p）q, (1-p)（1-q）となることが期待される。ところ が、QTLの変異がマーカーM を持つ個体で起こり $\mathrm{M}$ と $\mathrm{T}$ に強い関連性があれば、 $\mathrm{T}$ が選ばれるときに $\mathrm{M}$ も 同時に選ばれることになることから、M-T の組み合わ
せが生産性に有利なものとして選ばれ、その頻度だけ が他の組み合わせに比べて高くなる。こうして連鎖不 平衡が発生し、生産や生存性に有利な組み合わせが選 抜され、一家系でなく集団全体に広がっていくと考え られる。ゲノム上の SNP が乳生産に係る突然変異の多 くをとらえればとらえるほど SNP の育種的価值は高ま る。

農業の作物や家畜といった小さな集団（有効な集団 サイズ、 $\mathrm{Ne}$ ）ほど、連鎖不平衡が起こりやすくなる。 Lynch と Walsh（1998）は、二つの遺伝子間の連鎖不平 衡を $1 /(1+4 \mathrm{Ne} \times \mathrm{c})$ と示した。なお、 $\mathrm{c}$ は遺伝子間の 地図距離（モルガン）である。連鎖不平衡は選抜だけ でなく、偶然や遺伝組成の異なる集団の交雑（移動） によっても起こる。世代の更新時には組換えが起こり、 ある連鎖は偶然に消え、ある連鎖は偶然に残る。組換 えは地図距離に従って起こるため、QTLにより近い マーカーとの連鎖が残ると考えられる。アメリカのホ ルスタイン種集団の有効な集団サイズは、500世代前 には 1,400 頭だったが、現在は 100 頭前後とされてお り（Sargolzaei ら 2008）、強い選抜に伴い15, 20, 21 染 色体では、連鎖不平衡が距離の離れた遺伝子間でも認 められた。

次に、この SNPをアメリカ（VanRaden ら 2009）で どうゲノム育種価にしたかについて説明する。

(1) 種雄牛の娘の産次や分娩月齢等の遺伝以外の影 響を除いた乳生産記録の平均值をデータにして、従来 の NM\$（net merit）の育種価で信頼度が $75 \%$ 以上であ る 1952-1998 年生まれの種雄牛 3,576 頭について SNP

\footnotetext{
連絡先：富樫研治

（独）農研機構北海道農業研究センター T 062-8555 札幌市農平区羊ヶ丘 1 番地 (email: tkenji@naro.affrc.go.jp)
} 
（マーカー）を解析した。SNPの変異のうち、解析に 有効なものとして 38,416 個を用いた。各々の SNP の 変異のパターンは $3 つ （$ 例：MM、 $\mathrm{Mm}, \mathrm{mm}$ ）で、 $\mathrm{M}$ と $\mathrm{m}$ の効果の差 (置換効果) を全ての SNPについて 推定する。推定した SNP 効果からゲノム育種価を求 め、娘牛が 10 頭以上いる1999-2002 年生まれの種雄 牛 1,759 頭について、従来の方法で得られる育種価か ら計算される PA（両親の育種価の平均值）と比較し た。な押、38,416 個の SNP 効果を推定する過程で、多 くの SNP 効果を 0 と置いて推定する手法をとった。 Solberg ら（2008）は、マーカー密度が高くなればな るほどSNP 効果が 0 となる確率は小さくなり、多く のマーカーが 0 以外の小さな効果を持つようになると した。つまり、マーカーの密度により SNP 効果推定モ デルを変える必要があると考えられる。また、ここで 推定した SNP 効果は 38,416 個あり、それを推定する 表型值を与える種雄牛は 3,576 頭と推定効果数に満た ないことから、SNP 効果を母数効果として扱うことは できない。そのため、SNP 効果を変量効果として扱う ことでこの問題を解決した。2008 年 4 月評価の候補種 雄牛に㧍ける一部の形質の PA とゲノム育種価の信頼 度（正確度の自乗）を表 1 に示した。全形質ともゲノ 厶育種価の信頼度が高く、平均で $20 \%$ 以上の精度向上 を認めた。これは、父と母が同じ全きょうだいの候補 種雄牛の場合、PA は全ての牛が同じ值となるが、ゲノ

\section{表 1. 両親の平均育種価（PA）とゲノム育種価の信頼度}

\begin{tabular}{lcc}
\hline \multicolumn{1}{c}{ 形 質 } & $\begin{array}{c}\text { PA } \\
\text { (両親の平均育種価) }\end{array}$ & $\begin{array}{c}\text { ゲノム育種価 } \\
(\text { 線形) }\end{array}$ \\
\hline ネットメリット & 30 & 53 \\
乳量 & 35 & 56 \\
乳脂量 & 35 & 65 \\
たん白量 & 35 & 58 \\
乳脂率 & 35 & 69 \\
乳たん白率 & 35 & 62 \\
生産寿命 & 27 & 42 \\
体細胞数 & 30 & 49 \\
娘の妊娠率 & 25 & 41 \\
決定得点 & 24 & 40 \\
蹄の角度 & 23 & 40 \\
前乳房 & 24 & 53 \\
乳房の深さ & 25 & 61 \\
前乳房の配置 & 24 & 49 \\
乳頭の長さ & 25 & 52 \\
全平均 & 27 & 49 \\
\hline
\end{tabular}

厶育種価は、全きょうだいの 1 頭 1 頭が別々の SNP 夕 イプを持つために異なる值となる。すなわち、今まで は全きょうだい 1 頭 1 頭の遺伝的能力の差を識別でき なかったが、SNP 解析により 1 頭 1 頭の遺伝的能力の 差をより正確に識別できることになる。ゲノム育種価 は、親が $\mathrm{QTL}$ 遺伝子 $\mathrm{T}$ と $\mathrm{t}$ を持つ場合、子供が受け取 る遺伝子効果は $(\mathrm{T}+\mathrm{t}) / 2$ でなく、実際に子供がもらっ た QTL 遺伝子と関係のある SNP マーカーの効果によ り計算するので、SNP の組み合わせの数だけ個体の識 別が可能となり、育種価の推定精度が高くなる。つま り、育種価成分のメンデルの分離効果を今まで以上に 正確にとらえることで、ゲノム育種価の正確度は高く なっている（Daetwyler ら 2007）。精度向上の別な要因 は、従来の育種価もゲノム育種価も遺伝子を直接とら えていないが、従来の育種価では多くの遺伝子をまと

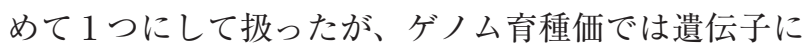
関連性の高いSNP を経由して個々の遺伝子効果を推定 する。すなわち、よりゲノム全体の遺伝子の実体に近 づいたといえる。また、個体間の近縁関係を血統情報 でなくSNP のタイプの似通い性を実際に調べて推定す る。つまり、ゲノムが個体間でどれだけ似ているかが、 従来の血統による期待的な数字からより実体に近づい たといえる。

(2) ゲノムには性決定に関与する染色体がある。雄 牛はXY という性染色体をもつ。雄牛はその X染色体 かY染色体のいずれかを子供に渡す。X染色体をもらっ た子供は娘牛、Y染色体をもらった子供は息牛になる。 娘牛の性染色体は XX であるため、父親の Y 染色体は 娘に伝わらない。したがって、娘の乳生産記録から Y 染色体にある SNP の効果は推定できず、推定できるの はX染色体にあるSNPの効果だけである。そのために、 1 頭の種雄牛が娘牛用と息牛用の 2 つの異なったゲノ 么育種価を持つ。娘牛用は推定した 38,416 個全ての SNP 効果を足したもの、息牛は父牛の X 染色体を受け 取っていないので、X 染色体にある SNP 効果を全体か ら引いたものが息牛用のゲノム育種価になる。

(3) 乳量のゲノム育種価を求めたい個体は、SNP の タイプを分析はするが、今までのように乳量の記録 を使わない。これは、38,416 個の SNP の MM、Mm、 $\mathrm{mm}$ の夕イプ毎の効果が過去の 1952-1998 年生まれの 3,576 頭の雄牛の解析から分かっていることから、乳 量記録がなくても SNPのタイプがわかればゲノム育種 価が推定できるためである。すなわち、遺伝率を 1.0 と仮定した状況に相当し、SNP のタイプさえわかれば、 38,416 個のマーカー効果の総和からゲノム育種価が計 
算できる。つまり、ゲノム育種価による改良は、選抜 個体の表型值なしでも高い精度で遺伝的能力推定值が 得られるという考えで牛づくりをするということであ る。しかし、選抜しようとする個体でなく1952-1998 年生まれの種雄牛 3,576 頭の記録から SNP 効果を推定 する際は、産次や分娩月齢等の遺伝以外の影響を除い た娘の乳生産記録の平均值、つまり表型値を使う必要 がある。マーカー効果を正確に推定するためには多く の表型值が必要であり、特に遺伝率が低い形質におい て SNP の効果がその形質の遺伝分散の多くを説明する ためには、従来の育種価推定と同様に多くの表型值が 必要である。ただし、その精度は前述の理由により従 来の育種価よりも高くなる。

ここで、選抜する個体はSNP だけに依存していいの か、つまり遺伝率を 1.0 として選抜していいのかとい う問題が拈きる。連鎖不平衡は世代が進むにつれて組 換えによって次第に平衡状態に近づいていく。このこ とがSNP 効果の推定精度を低下させる。例えば、先ほ どの連鎖不平衡の例で父から M-T、母から m-tをもらっ た牛がいるとする。この牛自身は M-T/m-t というマー カーと QTL の組み合わせを持っている。マーカーと QTL との関係が強ければ、この牛の子供の多くは M-T あるいは m-tをもらうことになるが、組換えによって M-t または m-T を持つ子供も生じる。とすれば、親で はM が良いマーカーだったとしても、子供の世代では 良くない遺伝子 $\mathrm{t}$ とリンクしたものも生じる。つまり、 マーカーの精度が低下しゲノム育種価の精度が低下す る。そもそも QTL が不明であれば、 M-t または $\mathrm{m}-\mathrm{T} を$ 持つ個体が集団の中にはじめから存在している可能性 もあり、同様にゲノム育種価の精度を低下させる要因 となる。また、飼養環境は時代とともに変わり、新し い飼料、例えば TMR 飼料が過去に使われてない場合 は、ゲノム育種価は TMR を用いた新しい飼養環境下 で遺伝能力がどう発揮されるかを示していない。この ことから、酪農家が新しい飼養環境でゲノム育種価を 使う場合は不安が残る。過去に測定された表型值から 推定した SNP 効果を新たな表型値を測定せずに使う際 は、表型值無しのSNP だけによる選抜が本当に遺伝 的能力を高めたか否かの検証が必ず必要になる。した がって、ゲノム育種価の推定には SNP だけでなく乳量 等の表型值や血統情報も加えていく必要がある。将来 的にゲノム育種価を用いた育種改良を行うためには、 遺伝的能力の推定精度をより高くする、牛群検定規模、 産業的スケールの育種体制の検討が必要になる。この 際、SNP から推定される個体間の似通いと従来の血縁
から推定される似通いを区別しないと、似通いをダブ ルカウントすることになり推定精度が低下すると思わ れる。SNP 解析と表型值の測定を継続的に行いながら 頻繁にマーカー解析をすることは、新しいマーカーの 発見にもなり、既知の有効なマーカーが遺伝的に固定 されたとしても、新マーカーによる新たな改良を可能 にしたり、新らしいQTLをみつけることも可能にす る。つまり、過去の表型值から SNP 効果を推定し現在 の選抜に使うのでなく、短期的にはコスト高かもしれ ないが、現在の評価と同じように表型值が得られる毎 にSNP 効果を再推定することが、ゲノム育種価の推定 精度を上げるとともに、継続的な改良を確保し、酪農 家の信頼を高めることになると考えられ、長期的には 低コストゲノム育種になると思われる。現在の育種価 やゲノム育種価は遺伝子の同定や機能性の解明を必要 としないが、QTL がマッピングされ同定された後、機 能性が判明すればその機能性を活用する方向で、マー カーでなく QTL そのものをゲノム育種価に取り組み、 生理的、生物的に裹付けされた育種価の推定や育種の 取り組みが具体的に進むと考えられる。

\section{2. オーストラリア、ニュージーランド、オランダで のゲノム育種価への取り組み}

オーストラリアでは 798 頭の種雄牛に扔ける 38,259 個の SNP, ニュージーランドでは 4,500 頭の種雄牛にお ける 44,146 個の SNP 、オランダでは 1,583 頭の種雄 牛に扔ける 46,529 個のSNPの解析結果を用いゲノム 育種価の精度を調べた。いずれも従来の育種価よりも 精度が高く、また多くの種雄牛を用いるほど精度が高 くなった。マーカー効果の推定は、QTL の効果の多く を 0 とした方が、全ての QTL が小さな効果を持つと した方法よりも精度は高いが、その差は 1-7\%と小さ かった。これは、従来からいわれているポリジーン的 な小さな効果を持つ遺伝子座が多く存在するというこ とがほぼ正しい事を示し (Hayes ら 2009)、ゲノム育 種価でも依然として小さな効果の多くの QTL 効果を推 定するために多くの表型值が必要であることを示して いる。オーストラリアでは、連鎖不平衡の程度を示す 隣接する遺伝子座間の遺伝子頻度を考慮した指数 $\left(\mathrm{r}^{2}\right.$ 、

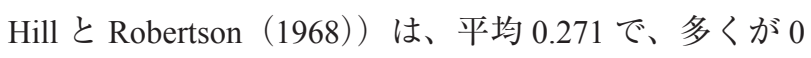
付近の值をとる分布であった。ゲノム育種価を最初に 報告した Meuwissen ら（2001）は、ゲノム育種価の精 度を高めるには $\mathrm{r}^{2}$ が 0.2 以上必要とし、その条件で遺 伝率 0.5 の形質の正確度が 0.85 となるとした。つまり、 連鎖不平衡を前提としたゲノム育種価の正確な推定に 
は、ゲノム全体で一様に高い $\mathrm{r}^{2}$ を得るためのゲノム全 体に渡る高密度なマーカーが必要である。

ニュージーランドでは、ホルスタイン種で推定され たマーカー効果がジャージー種には当てはまらず、他 の品種でも精度が低かった。このことは、連鎖不平衡 の特定な連鎖の相 (linkage phase: M-T) がホルスタイ ン種では乳生産に有利でも、同じ相 (M-T) がジャージー 種では乳生産に有利でないことを示している（Harris ら、2008)。Goddard と Hayes（2007）は、アンガス種 とホルスタイン種においてマーカーと QTL が同じ相 を確保するには、その距離が 10kb 以下でなければな らないとした。つまり、マーカーと QTL との連鎖の 相は種を超えて共通ではない。しかし、今後インター ブルではゲノム育種価を使った国際評価の時代を迎え る。その際は種や国をこえて有効なマーカーが必要で あり、マーカーとして 30 万個の SNP が必要である（De Roos ら 2008)。つまり、現在よりも高密度なマーカー により、日本とアメリカの両方に有効なマーカー、ア メリカにしか有効でないマーカー、日本にしか有効で ないマーカーを識別しなければならない。30万個の SNP 効果を精度よく推定するには、今まで以上の表型 值が必要であり、国際間の協力なしでは進まない。さ らに、QTL と QTL 間、QTL とマーカー間の関係で説 明出来なかったポリジーン効果や、QTL と飼養環境 との間に交互作用（Lillehammer ら 2007）がある場合、 QTL 効果が集団により異なる可能性がある。特に、異 なる遺伝組成を持つ集団間で比べた場合、QTL 効果 は交互作用の影響により集団間で一様でない場合が多 くなる。そのため、一つの飼養環境で推定されたマー カー効果の他の環境への当てはまりが悪くなり、ゲノ 么育種価の推定精度が低下すると思われる。なお、ア メリカも含めていずれの国も、個体の遺伝的能力をゲ ノム育種価としての SNP 効果と従来のポリジーン効 果（PA あいは表型值）を足して計算している。そ の理由は、1）SNPがすべての遺伝分散を説明できな いこと、特に連鎖不平衡 $\left(\mathrm{r}^{2}\right)$ が小さく 0.1 以下の時は ポリジーンを含めることは精度を高める（図 1、Calus と Veerkamp 2007)。ただし、ポリジーンなしでもゲ ノム育種価の正確度は、遺伝率が 0.1 ないし 0.5 の場 合、それぞれ 0.38-0.55 および 0.73-0.79 と、従来の育 種価（BLUP；最良線形不偏推定）による選抜より高 い。2）大きな効果をもつ QTL のみを改良の対象に した場合は、その QTL のタイプを固定してしまえば 改良は終わる。そのため長期選抜では、ゲノム育種価 のみの選抜は従来の BLUP 法による選抜量を下回ると

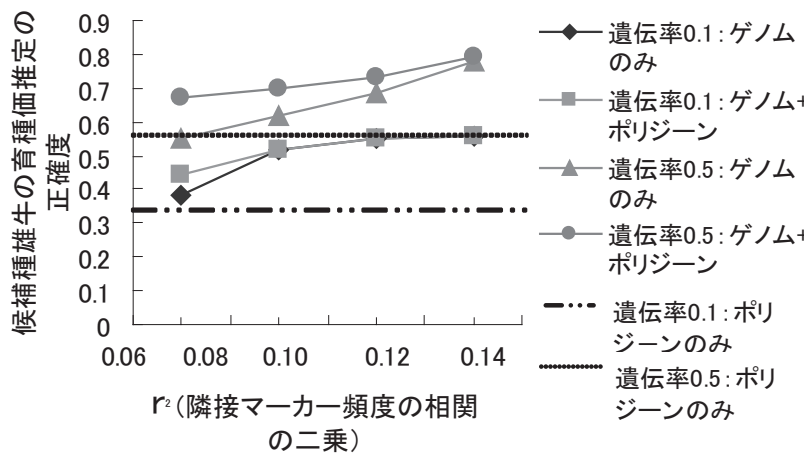

図 1 . ゲノム育種価による遺伝率 0.5 と 0.1 の場合の候補 種雄牛選抜の正確度

した（Muir 2007）。一方、ポリジーンは小さな効果を もつ多くの遺伝子座なので、それをゲノム育種価に加 えることで遺伝的に固定するための時間が長くかかる 分、長期間の継続的な改良を可能にする。3）ゲノム 育種価は連鎖不平衡を利用したものだが、マーカーと QTL が連鎖平衡の状態にある場合もある。一方、ポリ ジーンは連鎖平衡、不平衡に拘わらず育種価を求めら れる。4）SNP 単独では、低頻度の好ましい QTL 遺 伝子をリンクさせにくい。そのため単独の SNP ゙なく 5-10 個の SNP の組み合わせが好ましいという報告も ある（Villumsen ら 2009）。ただし、SNP 数が増えると その組み合わせ数が多くなり、効果の推定精度が低く なる。また、10 個の SNP の特定の組み合わせがいい としても、SNP 数が多くなればなるほど内部での組換 えが多くなり、始めの好ましいSNP の組み合わせを維 持しにくい。Villumsen ら（2009）は、遺伝率が 0.02 と 0.3 の形質に押いて SNP が 5 ないし 10 個のハプロタイ プが一番ゲノム育種価の精度が高くなるとした。また、 SNP の数が 30 ないし 40 個と多くなるにつれ、世代が 進むと組換えが起こり精度は低下することから（図 2 , 3 )、最適な SNP の数は集団の連鎖不平衡の程度やゲ ノムでの分布、マーカー間の距離に依存するとした。 一方、ポリジーン効果あるいは表型值をゲノム育種価 に加えれば、頻度が低くても全ての QTLを取り込む ことができるため、最初は好ましい遺伝子が低頻度で あっても、選抜により次第にその頻度が高くなること で遺伝分散も大きくなり、改良に大きく貢献する。こ うして長期的な改良が確保できる。なお、低頻度でも、 その QTL 遺伝子が優れていることが判明している場合 は、マーカーによりその優れた遺伝子をとらえること ができる。しかし、低頻度の QTL 遺伝子が優れている のか否かが不明な時は、ポリジーンあるいは表型值で 扱うとその低頻度の遺伝子を失うことなく捕まえる可 


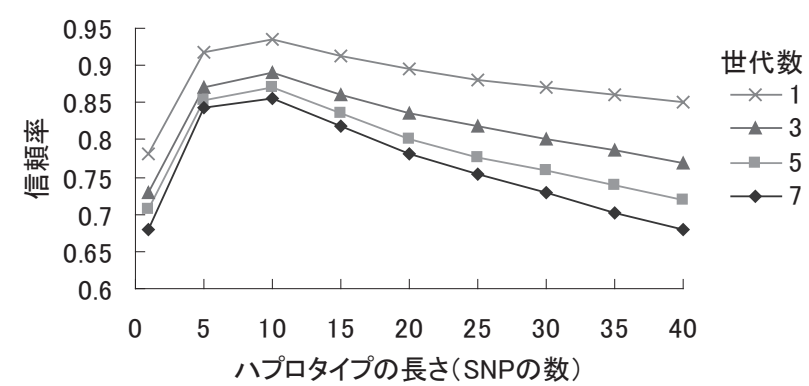

図 2.ハプロタイプ (SNP 数) の長さと世代数に伴うゲ ノム育種価の信頼率 $\left(\mathrm{h}^{2}=\mathbf{0 . 3}\right)$

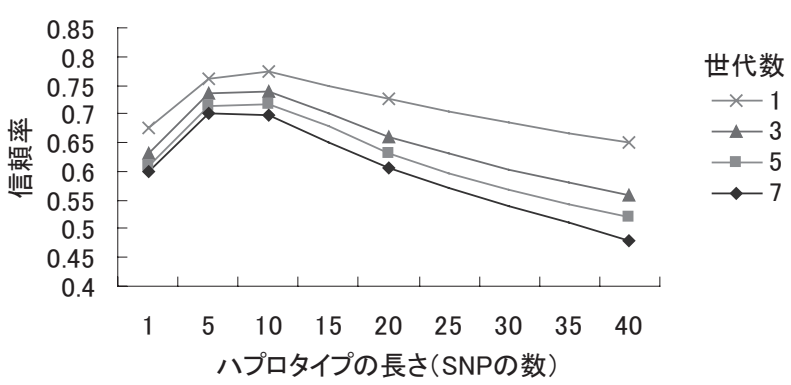

図 3.ハプロタイプ (SNP 数) の長さと世代数に伴うゲ ノム育種価の信頼率 $\left(\mathrm{h}^{2}=0.02\right)$

能性が高くなる。また、選抜初期には、大きな効果を 持つ遺伝子の固定を遅らせるために、大きな効果を持 つ遺伝子への選抜指数式の重みを軽くし、小さな効果 をもつ遺伝子の重みを大きくする。選抜の中期から後 期になるにつれ、その重みを逆転して最終的な反応量 を大きくすることもできる (Hayes ら 2009)。

アメリカを含むいずれの国でも、全きょうだいのゲ ノム育種価の推定精度が従来の育種価の精度よりも高 い利点を生かすため、現在の後代検定にゲノム解析の 結果をどう組み入れていくかが検討され始めている。
ニュージーランドでは、従来 300 頭の候補種雄牛数を、 ゲノム育種価により数千頭の中から予備選抜した 100150 頭に減らすことで、後代検定のコストを削減し、 かつ予備選抜にかける頭数を従来より増やすことで今 までより 50-60\% 高い改良速度が得られる（Harrisら 2008）としている。

\section{3. ゲノム育種価の利用法}

後代検定では、選抜された雄から次世代の雄また は雌へ、選抜された雌から次世代の雄または雌への 4 径路で選抜された効果が次の世代に伝わる。この 4 径路における現在の選抜割合、世代間隔、改良量を 表 2 に示した。雄から雄への世代間隔は 6.5 年と長い が、選抜の正確度は 0.99 と極めて高く、長い年数をか けて高い精度を得ている。全体の年あたりの改良量は $0.262 \sigma_{\mathrm{G}} /$ 年 $\left(\sigma_{\mathrm{G}}\right.$ は単位 $)$ となる。

次に、ゲノム育種価を用い後代検定を行わない例を 表 3 に示した（Schaeffer 2006）。雄牛は、1歳の時に 精液を授精し、子供はその約 9 ケ月に生まれるので世 代間隔は 1 才 +9 力月 $=1.75$ 年となる。すなわち従来 のように娘の成績で選抜するのでなく、1歳の時に自 分の SNP のタイプがわかり、そのタイプ毎の効果もわ かるので、それを用いれば後代検定なしでもゲノム育 種価は求まり、大幅に改良を早めることができる。し かし、雄から雄への経路における推定精度は、従来の 後代検定が 0.99 だったのに対し、ゲノム育種価では 0.75 と低い。つまり、種牛を生産する父牛のゲノム育 種価を用いた選抜では、遺伝的能力推定の精度は下が るが世代間隔を短くすることで改良速度が高まる。候 補種雄牛を生産する母牛は雄に比べて記録数が少ない ので、従来、2 産成績まで待って 4 歳で選抜している。

表 2. 現在の乳用種雄牛の後代検定における 4 径路からみた改良量

\begin{tabular}{|c|c|c|c|c|c|}
\hline \multirow[b]{2}{*}{ 径 路 } & \multirow[b]{2}{*}{ 選抜割合(\%) } & \multicolumn{2}{|c|}{ 正確度( $\left.\mathrm{r}_{\mathrm{TI}}\right)$} & \multicolumn{2}{|c|}{ 世 代 } \\
\hline & & 選抜差(i) & $\mathrm{r}_{\mathrm{TI}}$ & 世代間隔(L) & $\mathrm{i} \times \mathrm{r}_{\mathrm{TI}}$ \\
\hline 雄 $\longrightarrow$ 雄 & 5 & 2.06 & 0.99 & 6.50 & 2.04 \\
\hline 雄 $\longrightarrow$ 此倠 & 20 & 1.40 & 0.75 & 6.00 & 1.05 \\
\hline 此倠 $\longrightarrow$ 雄 & 2 & 2.42 & 0.60 & 5.00 & 1.45 \\
\hline 此倠 $\longrightarrow$ 此倠 & 85 & 0.27 & 0.50 & 4.25 & 0.14 \\
\hline 全 体 & & & & 21.75 & 4.68 \\
\hline
\end{tabular}

年当たり改良速度 $=i \times r_{T I} \times \sigma_{G} / \mathrm{L}=4.68 \sigma_{\mathrm{G}} / 21.75=0.2152 \sigma_{\mathrm{G}} /$ 年, $\sigma_{\mathrm{G}}=$ 遺伝分散の平方根. 
表 3. ゲノム育種価による選抜における 4 径路からみた改良量

\begin{tabular}{|c|c|c|c|c|c|}
\hline \multirow[b]{2}{*}{ 径 路 } & \multirow[b]{2}{*}{ 選抜割合(\%) } & \multicolumn{2}{|c|}{ 正確度 $\left(r_{\mathrm{TI}}\right)$} & \multicolumn{2}{|c|}{ 世 代 } \\
\hline & & 選抜差 $(i)$ & $r_{\mathrm{TI}}$ & 世代間隔(L) & $i \times r_{\mathrm{TI}}$ \\
\hline 雄 $\longrightarrow$ 雄 & 5 & 2.06 & 0.75 & 1.75 & 1.54 \\
\hline 雄 $\longrightarrow$ 雌 & 20 & 1.40 & 0.75 & 1.75 & 1.05 \\
\hline 雌 $\longrightarrow$ 雄 & 2 & 2.42 & 0.75 & 2.00 & 1.82 \\
\hline 此倠 $\longrightarrow$ 雌 & 85 & 0.27 & 0.50 & 4.25 & 0.14 \\
\hline 全 体 & & & & 9.75 & 4.55 \\
\hline
\end{tabular}
2.17 倍, $\sigma_{\mathrm{G}}=$ 遺伝分散の平方根.

表 4. 候補種雄牛を生産する母牛と候補種雄牛の予備選抜にゲノム育種価の 選抜を利用した際の 4 径路からみた改良量

\begin{tabular}{|c|c|c|c|c|c|}
\hline \multirow[b]{2}{*}{ 径 路 } & \multirow[b]{2}{*}{ 選抜割合(\%) } & \multicolumn{2}{|c|}{ 正確度 $\left(r_{\mathrm{TI}}\right)$} & \multicolumn{2}{|c|}{ 世 代 } \\
\hline & & 選抜差 $(i)$ & $r_{\mathrm{TI}}$ & 世代間隔(L) & $i \times r_{\mathrm{Tl}}$ \\
\hline 雄 $\longrightarrow$ 雄 & 2 & 2.42 & 0.99 & 6.50 & 2.40 \\
\hline 雄 $\longrightarrow$ 雌 & 20 & 1.40 & 0.75 & 1.75 & 1.05 \\
\hline 雌 $\longrightarrow$ 雄 & 2 & 2.42 & 0.75 & 5.00 & 1.82 \\
\hline 䧳 $\longrightarrow$ 雌 & 85 & 0.27 & 0.50 & 4.25 & 0.14 \\
\hline 全 体 & & & & 17.50 & 5.41 \\
\hline
\end{tabular}

年当たり改良速度 $=i \times r_{T I} \times \sigma_{\mathrm{G}} / \mathrm{L}=5.41 \sigma_{\mathrm{G}} / 17.5=0.309 \sigma_{\mathrm{G}} /$ 年 $=$ 従来の年当たり改良量の 1.44 倍, $\sigma_{\mathrm{G}}=$ 遺伝分散の平方根.

候補種雄牛が生まれるのは母牛が 5 歳ということで世 代間隔は 5 年となる。一方、ゲノム育種価の場合は、 雌牛の種付け時期を 15 力月齢とすると雄牛は 9 力月 後に生まれ、世代間隔は 2 年となる。15 力月齢時は乳 量記録がないので、SNPでゲノム育種価を計算する。 こうして世代間隔が短くなる。雌牛の選抜の精度は、 現在の育種価では記録数が少ないので 0.6 という值だ が、ゲノム育種価ではやや高く 0.75 となる。こうして ゲノム育種で精度を高めるということに限れば、雄牛 でなく今まで推定精度が雄に比べて低かった雌牛によ り活用できる。なお、世代間隔は雄も雌も短くし、改 良の速度を高めることになる。結局、4 経路すべてを 考虑した年当たりの乳量の改良量は $0.467 \sigma_{\mathrm{G}} /$ 年となり 従来の年当たり改良量の 2.17 倍となる。つまり、ゲノ 么育種価利用の従来法に対する優位性は、選抜の正確 度の影響よりも世代間隔を大幅に短くできることにあ
る。逆に、現在の後代検定は年数をかけ全国的な規模 で乳生産記録をとり、非常に精度の高い検定が行われ ていることを示している。

次に、後代検定をしながら雄牛の予備選抜（候補種 雄牛の選定）でゲノム育種価を用い、その候補種雄牛 を従来の後代検定にかける事例を紹介する。雄から雄 の径路で、従来の選抜圧 $5 \%$ の時と同じ数の検定済み 種雄牛を供給しながら、予備選抜により $2 \%$ の選抜圧 と同じ改良効果を得る。候補種雄牛を生産する雌牛は、 従来と同じ 4 歳までの乳生産記録に加えゲノム育種価 も用い選抜の精度を高める。検定は従来と同じ年数で 酪農家の飼養環境で行い、従来の表型值に SNP を加え て育種価の推定を行うことで、現在よりも高い推定精 度を持つ検定済み種雄牛を生産する。こうして年当た りの乳量の改良量は $0.309 \sigma_{\mathrm{G}} /$ 年となり従来より約 4 割 高い年当たり改良量が得られる（富樫 2008、表 4 ）。 
また、ゲノム育種は、近交上昇を従来に比べ軽減す る。つまり、家系に重点を扔いた現在の選抜では、優 れた家系は、その家系の構成メンバーが選ばれる確率 が高くなるが、ゲノム育種では家系の構成メンバーそ れぞれの育種価を識別できるため、ある家系に集中す ることなく、優れた牛を家系の枠を超えて選抜するこ とを可能にし、近交の上昇を軽隇する。

最後に、我が国のホルスタイン種の遺伝特性を SNP でより詳細に分析することは、今まで見つけられな かった特性を明らかにし、それを利用した我が国ホル スタイン種集団を活用した牛づくりを一層可能にす る。なお、組織的・効率的な正確なゲノム情報の収集、 ゲノム分析と解析が必要になればなるほど、酪農家 と改良団体がより一緒になり、私たちで牛づくりをし ているというスタンスが必要になる。そのことがより 一層我が国のホルスタイン種づくりを強固なものにす る。

\section{引用文献}

Calus MPL, Veerkamp RF. 2007. Accuracy of breeding values when using and ignoring the polygenic effect in genomic breeding value estimation with a marker density of one SNP per cM. Journal of Animal Breeding and Genetics, 124: 362-368.

Daetwyler HD, Villanueva B, Bijma P, Woolliams JA. 2007. Inbreeding in genome-wide selection. Journal of Animal Breeding and Genetics, 124: 369-376.

De Roos APW, Hayes BJ, Spelman RJ, Goddard ME. 2008. Linkage disequilibrium and persistence of phase in Holstein-Friesian, Jersey and Angus cattle. Genetics, 179: 1503-1512.

Goddard ME, Hayes BJ. 2007. Genomic selection. Journal of Animal Breeding and Genetics, 124: 323-330.

Harris BL, Johnson DL, Spelman RJ. 2008. Genomic selection in New Zealand and the implications for national genetic evaluation. Proc. Interbull Meeting, Niagara Falls, Canada.

Hayes BJ, Bowman PJ, Chamberlain AJ, Goddard ME. 2009. Invited review: Genomic selection in dairy cattle: Progress and challenges. Journal of Dairy Science, 92: 433-443.

Hill WG, Robertson,A. 1968. Linkage disequilibrium in finite populations. Theor. Appl. Genet. 38:226-231.

Lillehammer M, Árnyasi M, Lien S, Olsen HG, Sehested E, Ødegård J, Meuwissen THE. 2007. A genome scan for quantitative trait locus by environment interactions for production traits. Journal of Dairy Science, 90: 34823489.

Lynch M, Walsh B. 1998. Genetics and Analysis of quantitative traits. Sinauer Associates Inc, Sunderland, MA.

Meuwissen THE, Hayes BJ, Goddard ME. 2001. Prediction of total genetic value using genome-wide dense marker maps. Genetics, 157: 1819-1829.

Muir WM. 2007. Comparison of genomic and traditional BLUP-estimated breeding value accuracy and selection response under alternative trait and genomic parameters. Journal of Animal Breeding and Genetics, 124: 342-355.

Sargolzaei M, Schenkel FS, Jansen GB, Schaeffer LR. 2008. Extent of linkage disequilibrium in Holstein cattle in North America. Journal of Dairy Science, 91: 21062117.

Schaeffer LR. 2006. Strategy for applying genome-wide selection in dairy cattle. Journal of Animal Breeding and Genetics, 123: 218-223.

Solberg TR, Sonesson AK, Woolliams JA, Meuwissen THE. 2008. Genomic selection using different marker types and densities. Journal of Animal Science, 86: 24472454.

富樫研治. 2008 (11). 乳用牛新育種法評価法に係る米国 調查報告. 畜産技術協会。

VanRaden PM, Van Tassell CP, Wiggans GR, Sonstegard TS, Schnabel RD, Taylor JF, Schenkel FS. 2009. Invited review: Reliability of genomic predictions for North American Holstein bulls. Journal of Dairy Science, 92: 16-24.

Villumsen TM, Janss L, Lund MS. 2009. The importance of haplotype length and heritability using genomic selection in dairy cattle. Journal of Animal Breeding and Genetics, 126: 3-13. 